\title{
The sporophyte of the Paleogene liverwort Frullania varians Caspary
}

\author{
Jochen Heinrichs ${ }^{1}$, Matt von Konrat ${ }^{2}$, Heinrich Grabenhorst ${ }^{3}$ and Alexander R. Schmidt ${ }^{*}, 4$ \\ ${ }^{1}$ Albrecht-von-Haller-Institut für Pflanzenwissenschaften, Abteilung Systematische Botanik, Georg-August-Universität Göttingen, \\ Untere Karspüle 2, 37073 Göttingen, Germany \\ 2 Department of Botany, The Field Museum, 1400 South Lake Shore Drive, Chicago, IL, U.S.A. \\ ${ }^{3}$ Nachtigallenweg 9, 29342 Wienhausen, Germany \\ ${ }^{4}$ Courant Research Centre Geobiology, Georg-August-Universität Göttingen, Goldschmidtstraße 3, 37077 Göttingen, Germany. \\ E-mail: alexander.schmidt@geo.uni-goettingen.de
}

\begin{abstract}
Received 13 January 2012

Accepted 30 January 2012

Published 3 August 2012

Key Words

amber

bryophyte

Eocene

We document the sporophyte of the extinct Frullania varians based on an inclusion in Late Oligocene Bitterfeld amber from Germany. The sporophyte consists of a short, ca. $45 \mu \mathrm{m}$ thick seta that exceeds the perianth only slightly; the elongate-ovate, acute valves of the opened capsule are about $225 \mu \mathrm{m}$ long, curved backwards and consist of an epidermal and an internal layer. Cell walls of both layers possess nodulose trigones. Several trumpet-shaped, unispiral elaters are fixed to the upper third of the internal valve layer. They have a length of ca. $150 \mu \mathrm{m}$ and a diameter of $15-18 \mu \mathrm{m}$. A subglobose structure of $19 \mu \mathrm{m}$ diameter is interpreted as a degraded spore. Fossil elaters and spores as well as capsule wall details of Frullaniaceae are described for the first time.
\end{abstract}

Jungermanniopsida

Oligocene

Porellales

\section{Introduction}

Numerous inclusions of leafy liverworts (Jungermanniidae) have been recognized in Eocene Baltic and Late Oligocene Bitterfeld amber but well preserved sporophytes are exceedingly rare (Grolle \& Meister 2004; see Standke 1998; Blumenstengel 2004; and Standke 2008 for stratigraphic assignments of the amber deposits). Liverwort sporophytes are delicate structures with fragile setae, and many extant species produce them only infrequently. Their infrequent occurrence and short lifetime may explain their rarity in the liverwort fossil record.

Here we describe the sporophyte of Frullania (subg. Microfrullania) varians Caspary, 1887, based on a liverwort inclusion in a piece of Bitterfeld amber. With more than 300 extant species (von Konrat et al. 2012), Frullania Raddi, 1818, is the largest genus of the Porellales, the epiphyte clade of the leafy liverworts (Heinrichs et al. 2005). Frullania is also the most diverse genus preserved in Baltic and Bitterfeld amber. Some
25 species have been described from these ambers, of which nine are currently accepted (Grolle 1985, 2003; Grolle \& Meister 2004; Heinrichs et al. 2012). Frullania is characterized by its often reddish pigmentation, incubous leaves divided in a dorsal lobe, a ventral laminar stylus and a ventral lobule often forming a water-sac, rhizoids originating at the base of usually bilobed underleaves, male inflorescences located on short, almost leafless spicate branches, and beaked perianths often provided with ridges and tubercles (Schuster 1992; Hentschel et al. 2009). The supraspecific classification of Frullania is largely based on gametophytic characters (von Konrat \& Braggins 2001a); however, Schuster (1992) and von Konrat et al. (1999) emphasized the importance of sporophytic characters for the classification of Frullania. Fossil sporophytes have so far been recognized only in the Eocene species Frullania baltica Grolle, 1985 (Grolle 1998) and F.schumannii (Casp.) Grolle, 1981 (Grolle \& Meister 2004). However, their state of preservation only allowed for appraisals of their dimensions; details of the wall struc-

* Corresponding author 
tures and the content of the capsules remain unknown. In contrast, the newly described Frullania varians sporophyte allows for a description of elaters, spores, and some details of the capsule wall.

\section{Material and methods}

Bitterfeld amber pieces (Grabenhorst collection) with inclusions of Frullania were ground and polished manually with a series of wet silicon carbide abrasive papers [grit from FEPA P 600-4000 ( $25.8 \mu \mathrm{m}$ to $5 \mu \mathrm{m}$ particle size), firm Struers] to minimize light scattering for the investigation. All inclusions were studied using an incident-light microscope (Carl Zeiss Stemi 2000) and a transmitted-light microscope (Carl Zeiss AxioScope A1), each equipped with a Canon 450D digital camera. In some instances, incident and transmitted light were used simultaneously. The images of Figures $1 \mathrm{~A}-\mathrm{G}$ were obtained from several optical sections using the software package HeliconFocus 5.0 for a better illustration of the three-dimensional inclusions. Identification of the fossil plant material was carried out with the keys and descriptions of Grolle (1985) and Grolle \& Meister (2004); in some cases the inclusions were already identified by the late Riclef Grolle. Specimens of extant Frullania species from the following herbaria were examined using light microscopy and scanning electron microscopy as described by von Konrat et al. (1999) and von Konrat \& Braggins (2001a, b): Auckland War Memorial Museum, New Zealand (AK), University of Auckland, New Zealand (AKU), Natural History Museum London, UK (BM), Australian National Herbarium Canberra, Australia (CANB), Bairro Universitário, Criciúma, Brazil (CRI), Field Museum of Natural History, Chicago, USA $(\mathrm{F})$, Conservatoire et Jardin botaniques de la Ville de Genève (G), University of Göttingen, Germany (GOET), Royal Botanic Gardens Melbourne, Australia (MEL), University of Melbourne, Australia (MELU), Massey University, Palmerston North, New Zealand (MPN), Hattori Botanical Laboratory, Nichinan, Japan (NICH), New York Botanical Garden, New York, USA (NY), Muséum National d'Histoire Naturelle, Paris, France (P), Swedish Museum of Natural History, Stockholm, Sweden (S), Museum of New Zealand, Wellington, New Zealand (WELT) and University of Washington, Seattle, Washington (WTU).

\section{Results}

The inspection of some 30 amber inclusions of liverworts revealed several new fossils assignable to Frullania varians. Besides several sterile gametophytes we recognized autoecious gametophytes with short, budlike androecia and at best indistinctly beaked perianths with entire-margined gynoecial leaves and underleaves (Figs 1A-D). Bilobed, laterally ciliate underleaves were seen on several shoots (Fig. 1C). Amber piece Le 69 of the Grabenhorst collection comprises a few shoots of F. varians with a single sporophyte that exceeds the perianth only slightly. Both the sporophyte and the perianth under it were slightly damaged by former grinding and polishing; thus parts of the perianth wall and the sporophyte capsule were removed. However, the ca. $45 \mu \mathrm{m}$ thick seta and two valves of the opened capsule are still visible (Figs 1E, F). The elongate-ovate, acute valves have a length of $225 \mu \mathrm{m}$, and are curved backwards; their maximum diameter cannot be determined because of their embedding situation, and may be larger than $80 \mu \mathrm{m}$. Their epidermal layer has a brownish colour; cellular details are visible in the apical part of one valve (Fig. 1G). The apical epidermal cell has a triangular shape, the subtending epidermal cells are more or less rectangular with indistinctly visible corner thickenings in the form of short, rounded trigones extending towards the centre of the cell, and more elongate intermediate thickenings, possibly extending over the outer cell wall. The internal layer of the capule valves is visible for the lower $2 / 3$ of one valve, and consists of $+/-$ rectangular to elongate rectangular cells with irregularly shaped coarse wall thickenings; the basalmost cells without wall thickenings. Cells of the internal layers seem to form low ridges, however, it is possible that these structures are artifacts from the embedding process within resin. Seven unbranched, trumpet-shaped, unispiral, smooth elaters are visible with their apical ends fixed to the upper third of the internal layer of the valves (one valve with two, one with five elaters; Figs $1 \mathrm{E}-\mathrm{G})$. They have a length of ca. $150 \mu \mathrm{m}$ and a diameter of $15-18 \mu \mathrm{m}$ (central part). A subglobose structure with a diameter of $19 \mu \mathrm{m}$ at the perianth mouth likely represents a spore (Fig. $1 \mathrm{H}$ ); details of the spore surface are not visible.

\section{Discussion}

The extinct species Frullania varians is the most abundant liverwort of the Paleogene Baltic and Bitterfeld amber forests (Grolle \& Meister 2004). It has been assigned to the extant Southern hemispheric Frullania subg. Microfrullania (R. M. Schust.) R. M. Schust., 1982 (Figs 2A-D, F) on account of its minute size, Lejeunea-type branches, equally thickened, subquadrate leaf lobe cells, and entire-margined gynoecial leaves and underleaves (Grolle 1985). On the other hand, Frul-

Figure 1. Inclusions of the leafy liverwort Frullania varians Caspary in Bitterfeld amber from latest Oligocene strata of central Germany. A. Overview showing several gametophytes in ventral view; B. Autoecious gametophyte with a perianth (arrowhead) and two male inflorescenses on short, lateral branches (ventral view); C. Portion of gametophyte with two lateral, bud-like androecia (ventral view); D. Portion of shoot (ventral view) with a perianth and entire-margined gynoecial leaves and underleaf; E. Perianth and sporophyte; two valves are visible, each with several trumpet shaped, unispiral elaters with their apical ends fixed to the inner layer of the valves; F. Ibid, close up with arrowhead pointing to a degraded spore; G. Recurved valve with two elaters; the epidermal cells with indistinctly visible corner thickenings in the form of short, rounded trigones extending towards the center of the cell, and more elongate intermediate thickenings, possibly extending over the outer wall of the cell; H. Degraded spore. AC: Grabenhorst collection Le 41; D-H: Grabenhorst collection Le 69. Scale bars $1 \mathrm{~mm}$ in A, $100 \mu \mathrm{m}$ in B-F, and $10 \mu \mathrm{m}$ in G and $\mathrm{H}$. 


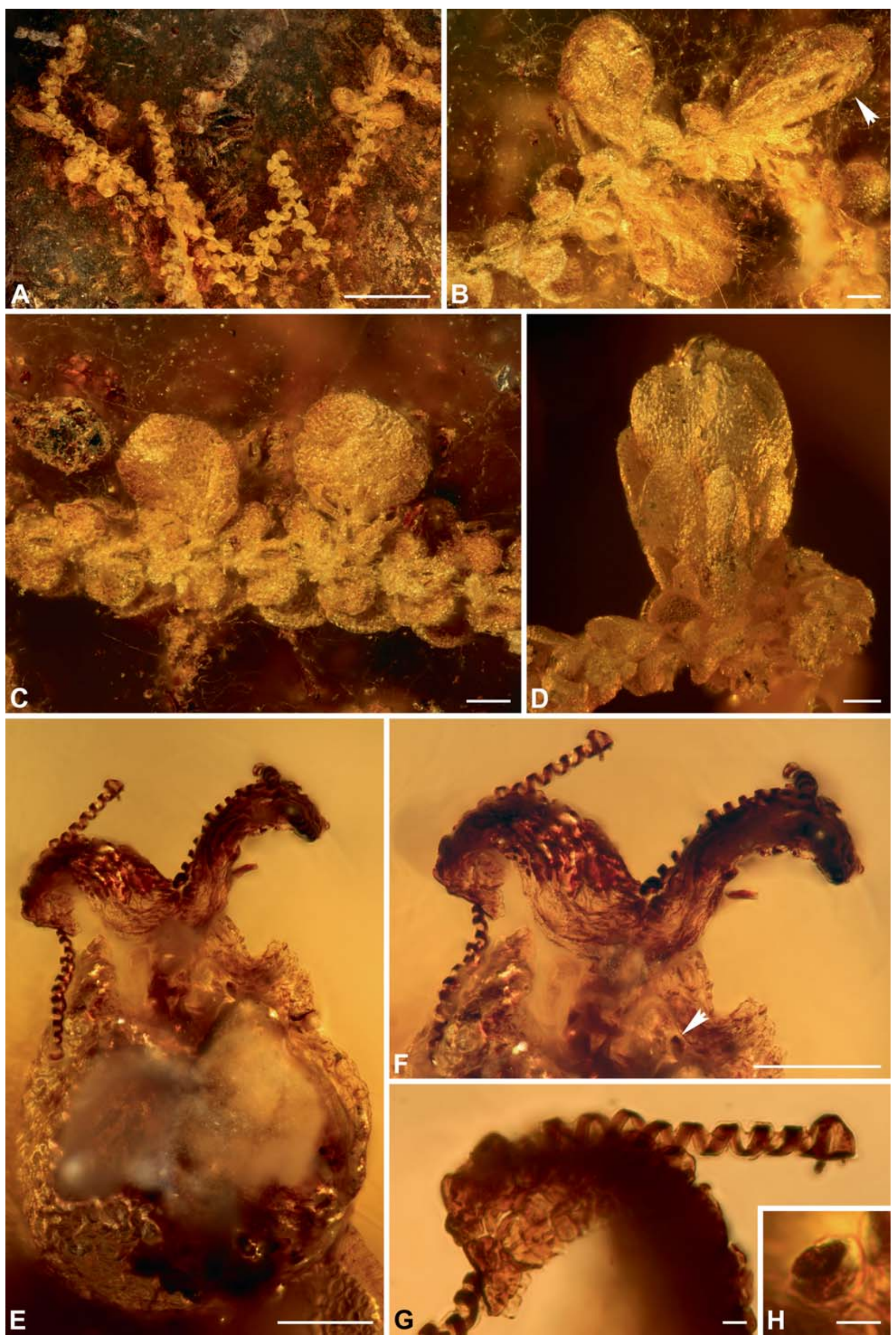



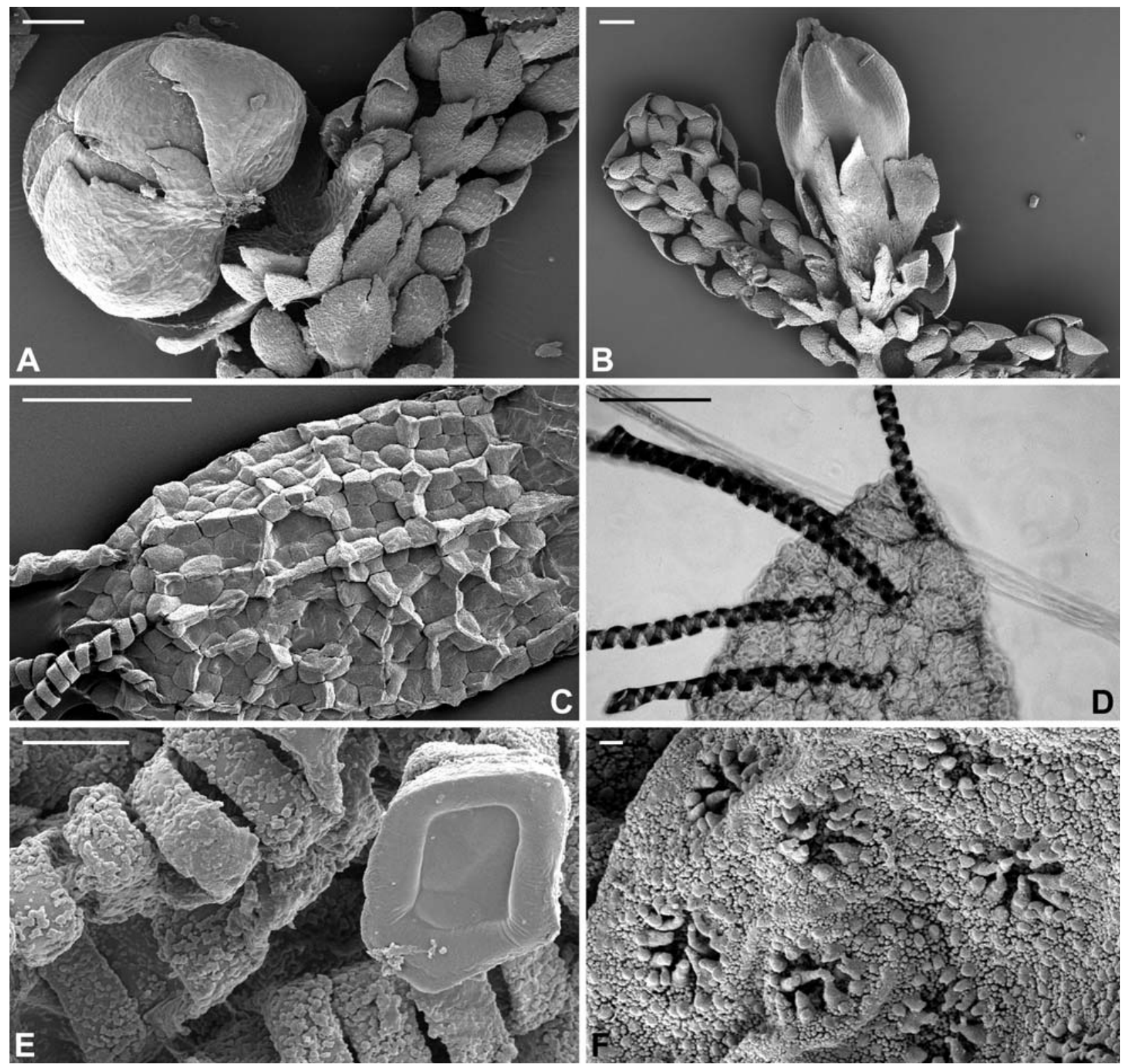

Figure 2. Morphology of extant Frullania. A. Part of shoot with androecium, ventral view; B. Part of shoot with gynoecium, ventral view; C. Internal layer of capsule valve with ridges and three elaters attached to upper third of valve; D. Upper third of valve with five elaters; E. Parts of unispiral elaters; end of one elater visible in the upper right part; F. Detail of spore with rosettes. A, C: Frullania (subg. Microfrullania) lobulata (Hook.) Dumort., 1835; B, D and F: Frullania (subg. Microfrullania) rostrata (Hook.f. \& Taylor) Hook.f. \& Taylor, 1845, and E: Frullania (subg. Frullania) incumbens Mitt., 1855. Scale bars $100 \mu \mathrm{m}$ in $\mathrm{A}-\mathrm{D}, 10 \mu \mathrm{m}$ in $\mathrm{E}$, and $1 \mu \mathrm{m}$ in $\mathrm{F}$.

lania varians has narrow styli and helmet-shaped watersacs that are oriented parallel to the stem, with low distance, resembling those of the extant Frullania (subg. Frullania) fugax (Hook. F. \& Taylor) Gottsche, 1845 (Hentschel et al. 2009) rather than extant representatives of subg. Microfrullania. Classification systems for extant Frullania species can be tested using molecular phylogenies (Hentschel et al. 2009). These phylogenies allow to identify characters that support supraspecific entities as well as homoplasious characters that cannot be used for classification. However, such kinds of data are usually not available for fossil taxa, hence; a certain probability of error must be accepted in taxonomical assessments of fossils. The more complete a morpholo- gical description of a fossil is, the more reliable its taxonomic treatment.

The newly described sporophyte of $F$. varians allows to further complete the detailed species description of Grolle (1985) and Grolle \& Meister (2004), and lends further support to the position of the Paleogene $F$. varians in F. subg. Microfrullania. The capsule of extant Frullania consists of four valves, each possessing an epidermal and an internal layer (Kamimura 1961; Yuzawa 1991; Schuster 1992; von Konrat et al. 1999). The capsule wall is often heavily pigmented and in smaller species, especially those of $F$. subg. Microfrullania, the valves may only range from $250-700 \mu \mathrm{m}$ long and $180-450 \mu \mathrm{m}$ wide. Both capsule wall layers consist of 
cells with variously shaped cell wall thickenings. These characters are present in F. varians, which possesses very small valves with a length of only ca. $225 \mu \mathrm{m}$. We do not know if the dimensions of the valves would be similar when studied in water or whether the embedding process in amber is connected with some shrinking processes. However, we do not expect extreme size deviations of valves embedded in resin or water respectively; hence the small size of the observed valves further supports an assignment of F. varians to F. subg. Microfrullania. Ridges on the inner capsule wall layer have also been seen in extant representatives of $F$. subg. Microfrullania (Fig. 2C).

Like most other liverworts, the capsules of extant Frullania species include both spores and elaters. In general, spores of Frullania are subglobose with diameters from (20)35-55(70) $\mu \mathrm{m}$ and possess a surface that is covered with rosettes; each rosette is formed of several variously shaped stelae (Schuster 1992; Weis 2001; von Konrat et al. 2011). Stelae of F. subg. Microfrullania representatives lack secondary branches and deposits (Hentschel et al. 2009). The observed single $F$ varians spore is at the lower end of size variation observed for spores of extant Frullania; details of the spore wall are unfortunately not visible. Frullania elaters have trumpet-shaped ends and remain connected to the inner layer at the distal end of the valves after spore release. They are nearly all consistently unispiral (Figs 2C-E), however, partly bispiral elaters have been observed in the extant species F. ericoides (Nees) Mont., 1839 (Schuster 1992), F. grandistipula Lindenb., 1845 (Nath 1984) and F. incumbens Mitt., 1855 (Weis 2001 [as F. "procumbens"]). The dimensions of the elaters vary from (110-)150-450 $\mu \mathrm{m}$ long and $15-35 \mu \mathrm{m}$ in diameter (Schuster 1992; von Konrat \& Braggins 2001b; Weis 2001). A range in the number of elaters per capsule occurs from 10-20 for F. (subg. Microfrullania) microcaulis Gola, 1923, to 110-120 for F. (subg. Chonanthelia) riojaneirensis (Raddi) Spruce, 1884 (Yuzawa 1991; Schuster 1992; von Konrat et al. 2011); however, the vast majority of Frullania species has more than 5 elaters per valve, with low interspecific variation (Schuster 1992). Although it is possible that a few elaters of the studied $F$. varians sporophyte were removed during the embedding process, their low number remains indicative of $F$. subg. Microfrullania.

The fragile seta of extant Frullania sporophytes exceeds the perianths only slightly and varies in size from the base to the apex. In cross section it is made up of 16-40 rows of epidermal cells and 4-55 rows of internal cells (Hattori \& Mizutani 1982; Schuster 1992); representatives of subg. Microfrullania possess only some 16-26 rows of epidermal cells and 4-22 rows of internal cells. Although we were unable to count the epidermal cells of the $F$. varians seta, we expect a low number of cells on account of its small diameter.

In summary, the Frullania varians sporophyte fits the morphology of F. subg. Microfrullania, corroborating the importance of sporophytic characters for the su- praspecific classification of Frullania and liverworts in general. Mastigolejeunea contorta (Göpp. \& Berendt) Gradst. \& Grolle, 2004, is the only other liverwort from Baltic or Bitterfeld amber of which some details of capsule walls and elaters have been described (Weis 2001 [as Trocholejeunea sandvicensis (Gottsche) Mizutani, 1962]; Grolle et al. 2004). Weis (2001: 112-13) recognized funnel shaped elaters with 1-2 spiral bands and an internal capsule wall layer with plurifenestrate incrassations, characters that are also seen in extant Mastigolejeunea (Spruce) Schiffner, 1893, species. Additional liverwort sporophytes have been recognized in Paleogene amber inclusions of Radula oblongifolia Caspary, 1887 (Grolle 1989) and Scapania hoffeinsiana Grolle, 2001 (Grolle \& Schmidt 2001), however, preservation of the latter allowed only for descriptions of the capsule shape or valves respectively. It remains to be seen if the increased interest in plant inclusions in amber (Grolle \& Meister 2004; Frahm 2010) will lead to the discovery of further fossil liverwort sporophytes, and whether these sporophytes will also match the morphology of extant taxa.

\section{Acknowledgements}

We thank the late Riclef Grolle for help with identifications, the herbaria AK, AKU, BM, CANB, CRI, G, MEL, MELU, MPN, NICH, NY, P, S, and WELT for the loan of specimens and Eva Maria Sadowski (Göttingen) for the careful preparation of some inclusions as well as Leyla J. Seyfullah (Göttingen) for her help in the preparation of the manuscript. We are grateful to Jiří Váňa (Prague), Alfons Schäfer-Verwimp (Herdwangen-Schönach) and an anonymous reviewer for their constructive suggestions. This is publication number 84 from the Courant Research Centre Geobiology that is funded by the German Initiative of Excellence. Award No. 1145898 from the National Science Foundation is also acknowledged.

\section{References}

Blumenstengel, H. 2004. Zur Palynologie und Stratigraphie der Bitterfelder Bernsteinvorkommen (Tertiär). - Exkursionsführer und Veröffentlichungen der Deutschen Gesellschaft für Geowissenschaften 224: 17.

Frahm, J. P. 2010. Die Laubmoosflora des Baltischen Bernsteinwaldes. Weissdorn Verlag, Jena.

Grolle, R. 1985. Monograph of Frullania in Baltic amber. - Prace Muzeum Ziemi 37: 87-100.

Grolle, R. 1989. Weitere Lebermoosfunde in Bitterfelder Bernstein, darunter Radula oblongifolia Caspary mit Sporophyt. - Feddes Repertorium 100: 131-136.

Grolle, R. 1998. The Eocene hepatic Frullania baltica found with androecium, perianth and capsule. - Nova Hedwigia 66: 451-456.

Grolle, R. 2003. Frullania mammiligera sp. nov., a new Eocene species of Hepaticae found in Bitterfeld amber of central Germany. Courier Forschungsinstitut Senckenberg 241: 155-161.

Grolle, R. \& Meister, K. 2004. The Liverworts in Baltic and Bitterfeld Amber. Weissdorn Verlag, Jena.

Grolle, R., Meister, K. \& May Ling So 2004. New evidence on the taxonomic position of the Eocene Jungermannites contortus (Jungermanniales: Lejeuneaceae). - Cryptogamie, Bryologie 25: 117123. 
Grolle, R. \& Schmidt, A. 2001. A fossil Scapania with perianth and capsule in Bitterfeld amber (Eocene) from Germany. - The Bryologist 104: 362-366.

Hattori, S. \& Mizutani, M. 1982. A status of Amphijubula (Hepaticae) with special reference to the seta anatomy. - Journal of the Hattori Botanical Laboratory 52: 441-448.

Heinrichs, J., Gradstein, S. R., Wilson, R. \& Schneider, H. 2005. Towards a natural classification of liverworts (Marchantiophyta) based on the chloroplast gene $r b c \mathrm{~L}$. - Cryptogamie, Bryologie 26: $131-150$

Heinrichs, J., Reiner-Drehwald, M. E., Feldberg, K. von Konrat, M., Hentschel, J., Váňa, J. Grimaldi, D. A., Nascimbene, P. C. \& Schmidt, A. R. 2012. The leafy liverwort Frullania (Jungermanniopsida) in the Cretaceous amber forest of Myanmar. - Review of Palaeobotany and Palynology 169: 21-28.

Hentschel, J., von Konrat, M. J., Pócs, T., Schäfer-Verwimp, A., Shaw, A. J., Schneider, H., Heinrichs, J. 2009. Molecular insights into the phylogeny and subgeneric classification of Frullania Raddi (Frullaniaceae, Porellales). - Molecular Phylogenetics and Evolution 52: 142-156.

Kamimura, M. 1961. A monograph of Japanese Frullaniaceae. - Journal of the Hattori Botanical Laboratory 24: 1-109.

Nath, V. 1984. Abnormal elaters in Frullania grandistipula Ldbg. - a new record. - National Academy Science Letters 7: 297-298.

Schuster, R. M. 1992. The Hepaticae and Anthocerotae of North America East of the Hundredth Meridan. Vol. V. Field Museum of Natural History, Chicago.

Standke, G. 1998. Die Tertiärprofile der Samländischen Bernsteinküste bei Rauschen. - Schriftenreihe für Geowissenschaften 7: 93 133.
Standke, G. 2008. Bitterfelder Bernstein gleich Baltischer Bernstein? - Eine geologische Raum-Zeit-Betrachtung und genetische Schlußfolgerungen. - Exkursionsführer und Veröffentlichungen der Deutschen Gesellschaft für Geowissenschaften 236: 11-33.

von Konrat, M. \& Braggins, J. E. 2001a. A taxonomic assessment of the initial branching appendages in the liverwort genus Frullania Raddi. - Nova Hedwigia 72: 283-310.

von Konrat, M. \& Braggins, J. E. 2001b. Notes on five Frullania species from Australia, including typification, synonyms and new localities. - Journal of the Hattori Botanical Laboratory 91: 229263.

von Konrat, M., Harris, P. J. \& Braggins, J. E. 1999. A new technique to investigate cell layers of the capsule wall using Frullania (Hepaticae) as a case study. - The Bryologist 102: 240-248.

von Konrat, M., Hentschel, J., Heinrichs, J. \& Braggins, J. E. 2011. Deep Southern Hemisphere connections: a revision of Frullania sect. Amphijubula. - The Bryologist 114: 52-66.

von Konrat, M., de Lange, P., Greif, M., Strozier, L., Hentschel, J. \& Heinrichs, J. 2012. Frullania knightbridgei, a new liverwort (Frullaniaceae, Marchantiophyta) species from the deep south of Aotearoa-New Zealand based on an integrated evidence-based approach. - PhytoKeys 8: 13-36.

Weis, G. 2001. Morphologische und anatomische Untersuchungen der Sporophyten bei den Jubulaceae Klinggr. und Lejeuneaceae Casares-Gil (Hepaticae) und deren systematische Bedeutung. Bryophytorum Bibiliotheca 57: 5-302.

Yuzawa, Y. 1991. A monograph of subgen. Chonanthelia of gen Frullania (Hepaticae) of the world. - Journal of the Hattori Botanical Laboratory 70: 181-291. 